\title{
Modern Colonialism and Cultural Continuity Through Material Culture: An Example from Guam and CHamoru Plaiting
}

\author{
Sandra Montón-Subías ${ }^{1,2}$ (D) Almudena Hernando Gonzalo ${ }^{3}$
}

Accepted: 16 July 2021 / Published online: 28 August 2021

(c) The Author(s) 2021

\begin{abstract}
This article analyzes cultural persistence in Guam through plaiting, material culture, and maintenance activities, a set of daily practices that are essential to social continuity and well-being. The colonization of Guam began in 1668 with the Jesuit missions. Jesuit policies utilized maintenance activities to colonize Indigenous lifeways and subjectivities, but we believe those activities also functioned as reservoirs of traditional knowledge. Although plaiting has been situated in different historical contexts across the centuries, it no doubt expresses material continuities stretching from a precolonial past. The article also challenges today's widespread belief that the search for change is a universal value. It argues that societies appreciate continuity over change in inverse proportion to technological control over nature, asymmetrical relationships of power, and specialized fragmentation of functional tasks. In the absence of such features, the best guarantee of survival lies in maintaining the balance achieved by traditional lifeways.
\end{abstract}

Keywords Modern colonialism - Cultural persistence · Gender and material culture · Guam

\section{Introduction}

The archaeological literature emphasizing cultural persistence continues to grow in volume every year. This trend is grounded in Indigenous, postcolonial and feminist archaeologies (Atalay 2006; Colomer et al. 1998; Deagan 2004; Flexner 2014;

Sandra Montón-Subías

sandra.monton@upf.edu

1 Departament d'Humanitats, Universitat Pompeu Fabra, 08005 Barcelona, Spain

2 ICREA, Pg. Lluís Companys 23, 08010 Barcelona, Spain

3 Departamento de Prehistoria, Facultad de Geografía e Historia, Universidad Complutense, 28040 Madrid, Spain 
González-Ruibal 2014: 16-33; Hernando 2013; Lightfoot et al. 2017; Lydon 2009; Panich 2013; Pauketat 2001; Schreiber and Mitchell 2010; Silliman 2009; Swidler et al. 1997; Wright and Ricardi 2015) that have emphasized the need to establish cultural continuity in order to understand the past and how it has shaped the present. Cultural continuity has, however, traditionally been disregarded by mainstream analyses of cultural processes. The idealization of change-coupled with the Enlightenment notion of progress and the more recent concept of innovation-has resulted in the almost exclusive presence of dynamics of cultural change in narrations of the past. Human history, nonetheless, has been a combination of continuity and change (Hastrup 1992; Montón-Subías and Hernando 2018; Sahlins 1985: 144), although it has been expressed in various ways, because societies appreciate continuity over change in inverse proportion to technological control over nature, asymmetrical relationships of power, and specialized fragmentation of functional tasks (Hernando 2002). When this technological control does not exist, the best guarantee of survival lies in maintaining the balance achieved by traditional lifeways.

Despite today's widespread belief that the search for change is a universal value, ethnography portrays many societies that do not subscribe to "renew or die," but instead to perpetuating themselves in their customary ways of life (Appadurai 1990; Clastres 2014). In Europe, for instance, the concept of risk did not generalize in common speech until the seventeenth century (Giddens 1991: 111-112), when science and technology had developed sufficiently to make humans-or some humans-believe their power was superior to that of nature (Elias 2000; Hernando 2002; Merchant 1980; Mumford 1967). This was indeed a deep transformation in dominant mindsets because opening oneself up to an uncertain future began to be preferred over the traditional ways of doing things. The changing nature of modern knowledge and the introduction of abstract systems into daily life made change seem less threatening and more synonymous with progress, as would be so blatantly evident a century later in the Enlightenment (Elias 1987; Giddens 1991; Wagner 2016).

Importantly, our standpoint has nothing to do with romantic views of unmoving "primitive" societies, or with evolutionary interpretations of human history that equate stability with stagnation (Montón-Subías and Hernando 2018). Human explanations of the world (and of the people in it) seek to provide human beings with the idea that they will remain safe within it and will survive. Such explanations always convey the belief that one's own group has a greater chance of survival than any other (Hernando 2013, 2018). When reality is explained through science, the secret of survival lies in scientific explanations of nature's physics and in technological development, both of which are associated with a positive assessment of change (Midgley 2011). When reality is explained through myth, the secret of survival is found in safeguarding the traditional lifeways revealed by the sacred realm, which implies a negative assessment of change (Eliade 1959).

However, we do not seek to "binarize" societies according to the presence or absence of change because it is not possible to speak of societies with and without change as two antithetical and absolute poles (see Ardener 2012; Pezzarossi 2014). We could say that mythic explanations of the world and knowledge of nature's physics coexist in many societies. The tendency to change will appear gradually as divisions of functions, specialization of work, and social differentiation emerge and 
increase. It will be incarnated by those holding the most specialized or powerful positions. Confidence in the sacred realm will then be combined with confidence in one's technological control in order to neutralize ontological anxiety (Hernando 2002). The appearance of alphabetical writing and abstract reasoning will boost confidence in technology, but the actual inversion of the two perspectives will occur only since the Enlightenment (Midgley 2011).

Both attitudes (the quest for change and the quest for persistence) are equally operative, intelligent, functional, and successful because both provide ontological security to those who embrace them. From the Western perspective, we tend to think that only our way of understanding the world, reality, and ourselves has reached its zenith. We sometimes label those who value tradition and permanence over change as "backward" or "primitive." However, this is nothing but an ideological prejudice rooted in the Enlightenment's teleological vision of history, which considered Western society as the culmination of human development because it had dared to change over time (Kant (1991) [1784] is a clear example). From this position, it is not understood that change — or innovation or even creativity_does not rest on any moral grounding and is not good or bad in and of itself. Nor is it understood that all societies are equally complete even though they organize reality differently. Finally, it is not recognized that continuity and stability, despite forfeiting acknowledgement in Enlightenment mainstream discourse, have continued to operate up until the present day in the West as well.

Analyzing the relationship between change and continuity becomes more complex in studies of cultural interactions where contending parties weigh the two vectors differently. This seems to characterize many Indigenous-colonial interactions following the conquest and colonization of wide regions of the globe by the modern European powers. We focus in this article on Guam, the southernmost island of the Micronesian Marianas (Fig. 1). Guam was formally incorporated into the colonial network of the Hispanic Monarchy in 1565. However, its genuine and permanent colonization began more than a century later with the Jesuit missions. Native ways of making sense of the self and the world, including perceptions of time and attitudes towards change and continuity, were targeted from the outset.

Anticolonial, postcolonial, and decolonial scholars have long substantiated critiques of the Eurocentrism underlying many studies of colonialism. They have raised awareness of historical experiences undergone by Indigenous communities as constituting historical contributions of their own (Fanon 1961; Guha and Spivak 1988). Adopting this perspective, we explore new approaches to how cultural transformations and continuities interacted under colonial regimes. Although cultural transformations figured as a core intention of the colonial-missional domination of Guam, cultural continuities persisted on the island. Maintenance activities provide a suitable sphere in which to examine them. We have developed this concept, together with others (González Marcén et al. 2008), to refer to routine, recurrent, and quotidian practices that are essential to social continuity, stability, and well-being. They include (but are not limited to) basic food-processing, basic textile manufacture, basic hygiene, health and healing, the socialization and rearing of children, the provision of care, and the arrangement of living spaces. Jesuit policies clearly utilized maintenance activities to colonize Indigenous 


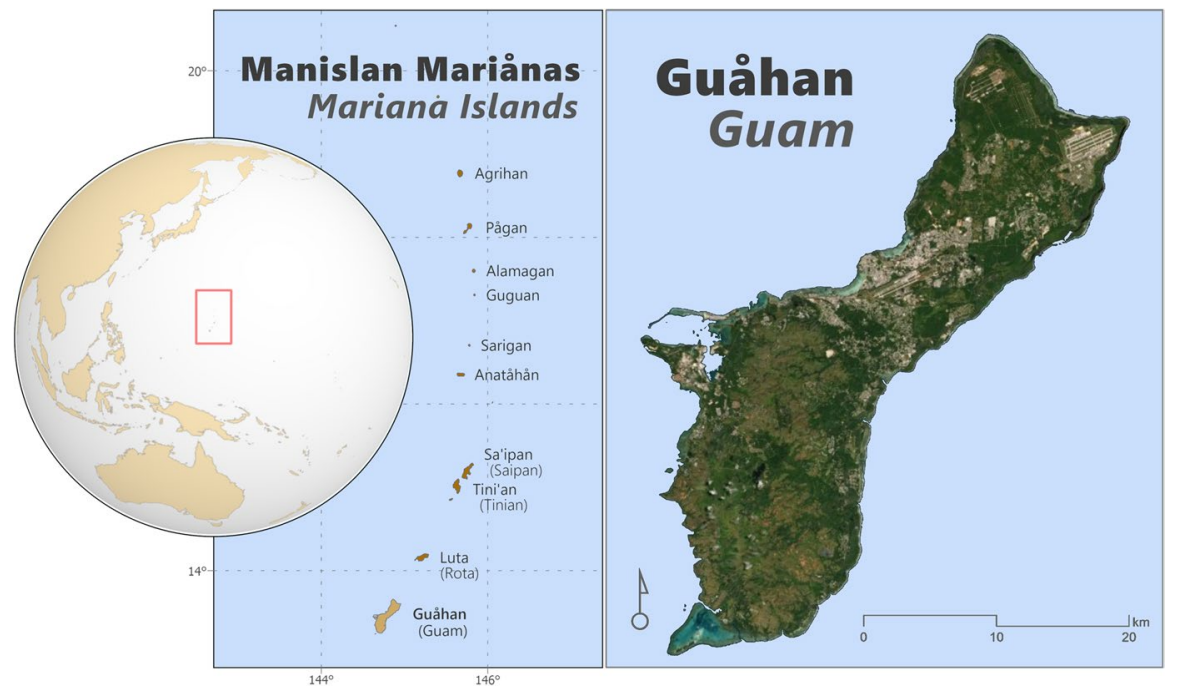

Fig. 1 Location of Guam and the Mariana Islands. Cartography by David Lloberas for ABERIGUA. Ortophoto: USDA, USGS, Esri Maxar, GeoEye, AeroGrid

lifeways and subjectivities (Montón-Subías 2019). But we believe those activities also functioned as reservoirs of traditional knowledge.

The importance of recovering the reality of cultural continuity is also evident in the strong efforts that Indigenous rights activists in many regions of the world-including Guam (Clement 2019; Diaz 1994; Leon Guerrero 2019; Na' puti and Lujan Bevacqua 2015; Perez Hattori 2007, 2018; Perez Viernes 2016; Souder 1992; Taitano DeLeslie 2015; and see Atienza 2019: 3) - are making to establish bonds with noncolonial pasts through the reinvigorating of tradition, including connecting and reconnecting with precolonial material culture (see also Flores 1999: 16-17). In this article, we will focus on textile manufacturing and plaited objects. A few years ago, while reviewing materials from the Marianas curated at the Spanish National Museum of Anthropology in Madrid, we noted some nineteenthcentury plant-weaved artifacts (Figs. 2, 3, and 4) that were very similar to descriptions and illustrations in precolonial sixteenth- and seventeenth-century documents (Fig. 5). Likewise, twentieth-century photographs show that at least some such plaited materials were still in use until the middle of that century (Fig. 6). Although appearing in different historical contexts, they no doubt express material continuities stretching from a precolonial past. 
Fig. 2 Nineteenth-century CHamoru doga or sandals weaved with coconut leaves (CE2156, right, and CE2157, left) at Museo Nacional de Antropología, (Madrid, Spain). Measures: CE2156 (height: $5 \mathrm{~cm}$; length: $19.3 \mathrm{~cm}$; width: $8.4 \mathrm{~cm}$ ); CE2157 (height: $5.2 \mathrm{~cm}$; length: $19 \mathrm{~cm}$; width: $8 \mathrm{~cm}$ ). Photograph by Patricia Alonso Pajuelo

Fig. 3 Nineteenth-century CHamoru fan plaited with coconut leaves, diagonal pattern (CE2136) at Museo Nacional de Antropología (Madrid, Spain). Measures: length: $40 \mathrm{~cm}$; width: $24.5 \mathrm{~cm}$; depth: $1.6 \mathrm{~cm}$. Photograph by Arantxa Boyero Lirón

Fig. 4 Nineteenth-century CHamoru basket plaited with pandanus leaves, diagonal pattern and double rim (CE6996) at Museo Nacional de Antropología (Madrid, Spain). Measures: height: $30 \mathrm{~cm}$; length: $40 \mathrm{~cm}$; width: $14.5 \mathrm{~cm}$. Photograph by Miguel Ángel Otero
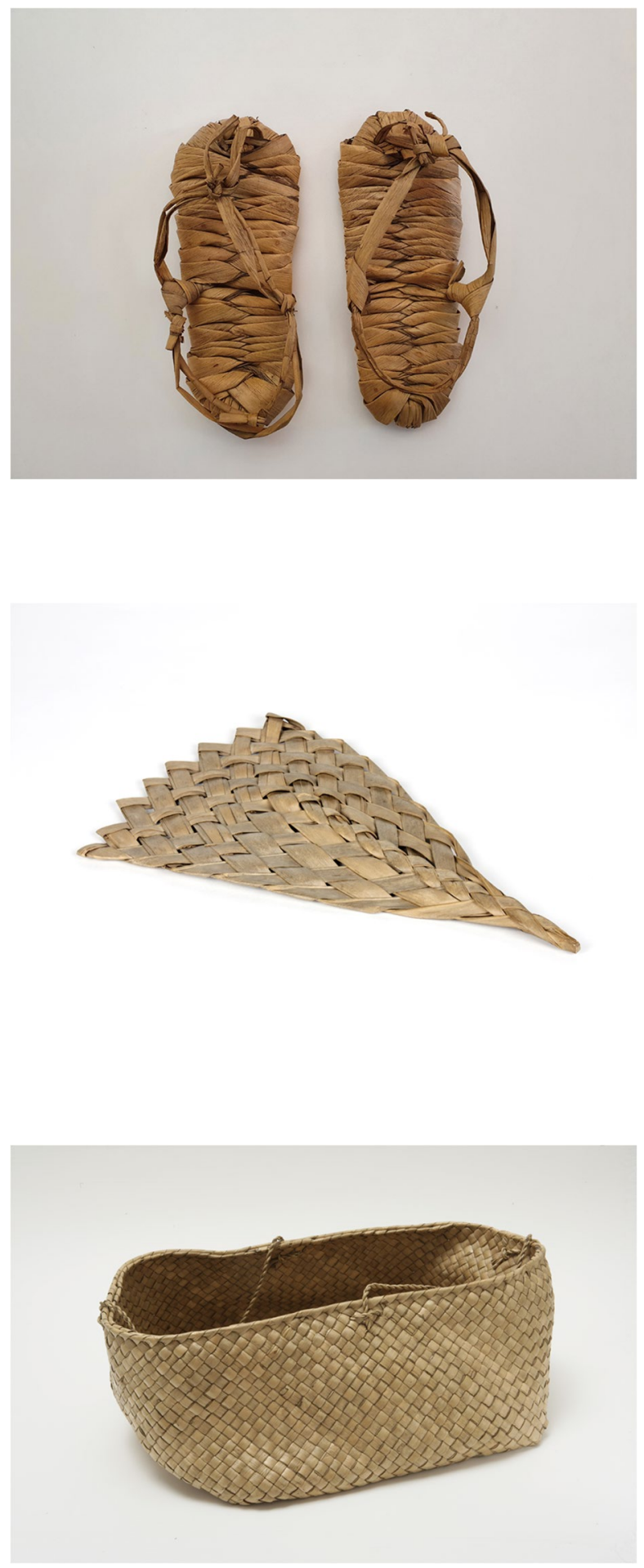
Fig. 5 CHamoru man with a plaited hat, Guam $1600 \mathrm{CE}(\mathrm{du}$ Nort 1602: 34)

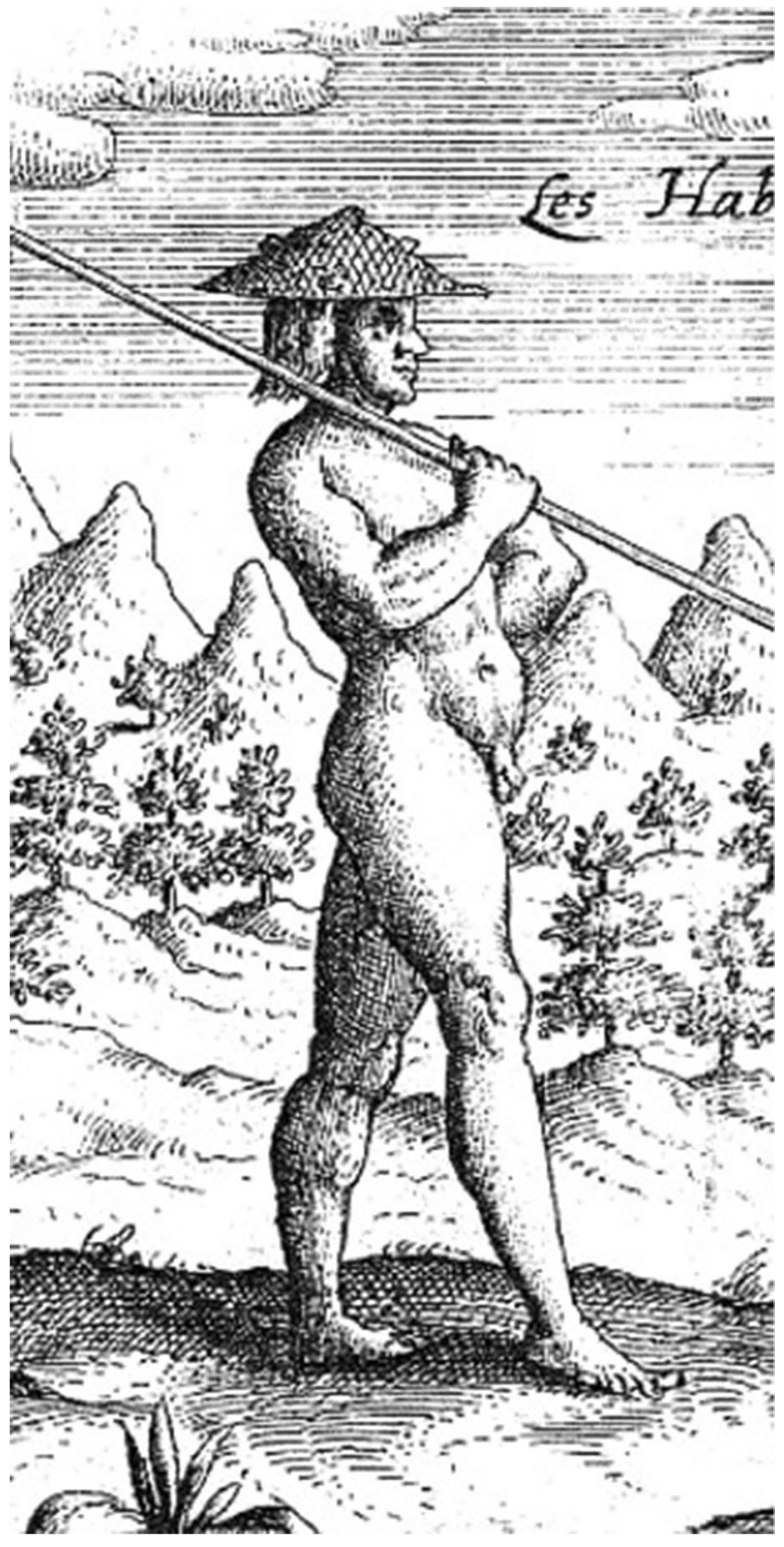

\section{Guam Before Modern Colonization}

At this time, Guam is an unincorporated territory of the United States. Unfortunately, colonialism is not new to the CHamoru people. (CHamoru/Chamorro is the name that the Indigenous inhabitants of Marianas use to refer to themselves. The Kumisión I Fino CHamoru [CHamoru Language Commission], based in Guam, recommends the "CHamoru” spelling [Taitano 2019; https:// 


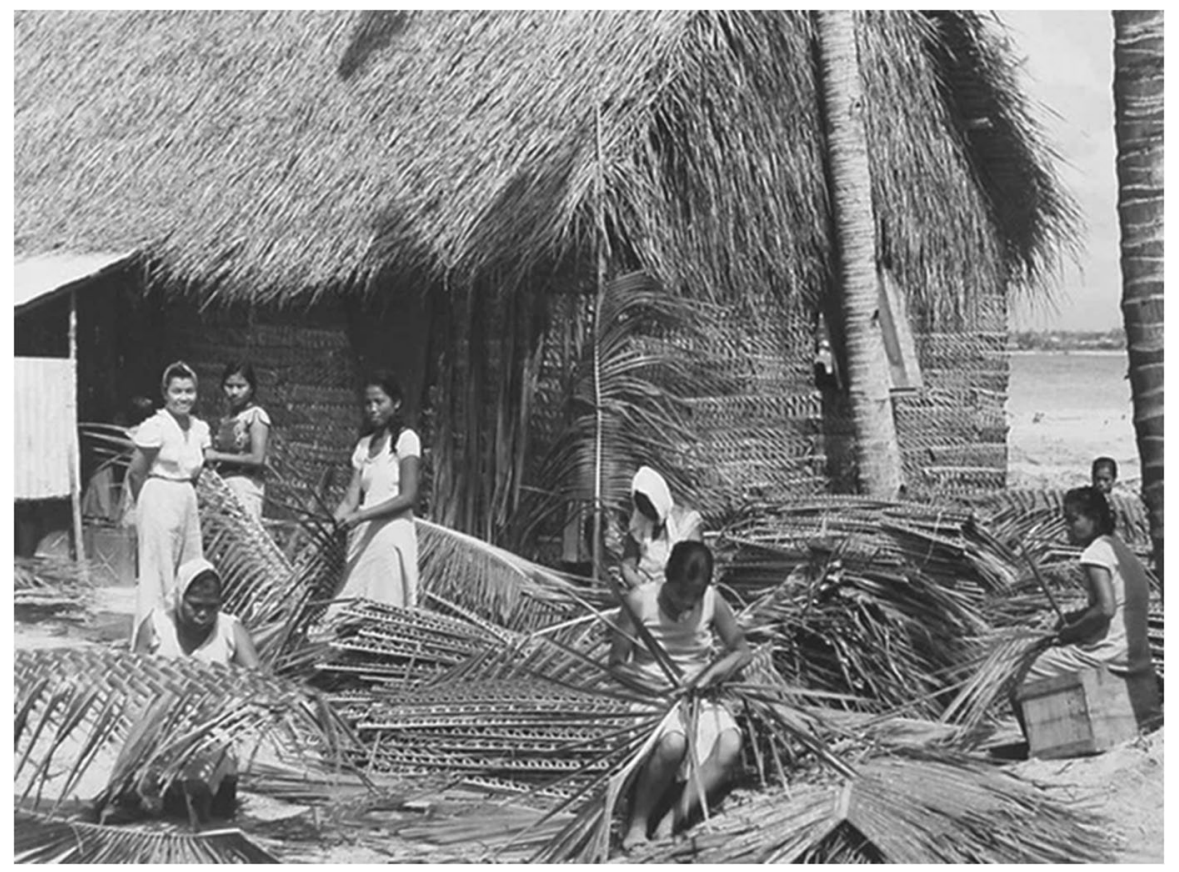

Fig. 6 Women thatching, Agat, Guam 1945. United States National Archives

kumisionchamoru.guam.gov/]. However, Chamorro is also used, and even preferred in the Northern Mariana Islands. As this article is mainly about Guam, we will use the CHamoru spelling.) They have endured occupation by Spanish, German, Japanese, and US imperial powers since the seventeenth century. Interactions with Europeans commenced even earlier, in 1521, when CHamorus canoed out to Magellan's fleet which had anchored in their waters while circumnavigating the world. Subsequent contacts intensified after the 1565 Legazpi expedition, when the Manila transpacific galleon route that realized the longdreamed-of round trip between Manila and Acapulco first began (Clossey 2006; Driver 1990; Giráldez 2015). Guam would often serve as a waystation on this route in subsequent years. Although Legazpi took formal possession of the Marianas for the Hispanic Monarchy in 1565, its actual and permanent colonization began later, in 1668, when Jesuit Diego Luis de Sanvitores established the first mission in Hagåtña, the current capital of Guam (Coello 2016; Driver 1988).

Although hostilities soon began, missionaries were initially welcomed by CHamoru Latte societies. Latte is a word likely deriving from Latde, the term CHamorus used in the nineteenth century to refer to the stone remains they believed had survived from their ancestors' houses (Russell 1998: 55). This is indeed what these remains are: stone foundations arranged in two parallel rows made of shafts (haligi) and semicircular capstones (tasa) to support thatched rooms on top (Fig. 7). Two main repertoires are informative of Latte societies: 


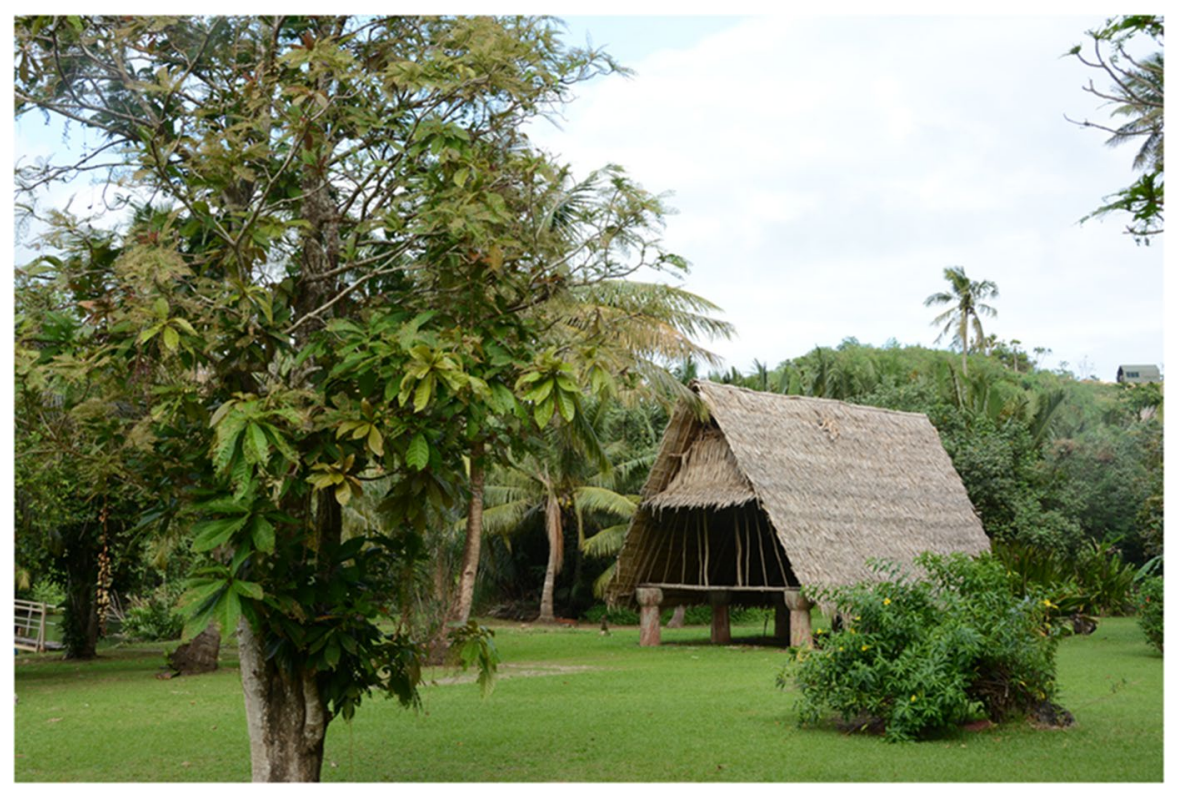

Fig. 7 Reconstruction of a Latte building by Talafofo River, Guam. Photograph by the author

the archaeological evidence and documents written until ca. 1700, when Latte villages seem to have vanished following a forced reduction process.

\section{Latte Communities in Historical Documents}

Between 1521 and 1668, a series of expeditions and missionary visits produced accounts that gathered some of the Latte CHamoru practices and customs (Pigafetta 1525; Pobre de Zamora 1599-1603; Kerr 2013). Post-1668 reports emphasized, in addition, some of the changes that occurred during the mission's early stages (Aranda 1690; García 1683; Ledesma 1670). These documents were written over a period of a century and a half, a lapse of time long enough to have witnessed social changes within Latte communities. Some of the inconsistences and contradictions in the documents might have, in part, a chronological explanation. They are invaluable for understanding Latte society before and during the first years of the colony, but they must be approached critically, with questions of who wrote them and for what purposes at the forefront of the inquiry. Early modern explorers and missionaries were not professional anthropologists. European societies were the norm against which CHamorus were measured, without any concern for subjective Eurocentric biases (see also Russell 1998: 143).

One of these contradictions refers to social organization and hierarchy. Magellan's chronicler, Antonio di Pigafetta, wrote that there were no lords among the natives of Guam (1525: fol. 17v), but other sources, including members of the same expedition (Lévesque 1992: 465), identified chiefs who were later called principales. In 
the early seventeenth century, Franciscan Juan Pobre de Zamora characterized the principales - he said were called magaries or macaries (Martínez 1997: 446) and chamuri (Martínez 1997: 467)—as those enjoying social respect and advantages but nonetheless having very limited power. He also noted ranked lineages. Later, in situ Jesuits classified these lineages into low, medium, and high (Ledesma 1670: 4; Lévesque 2000: 15; Sanvitores et al. 1671) but noted, again, the lack of social power of the chamorris' or chamoris' despite the fact that they were treated with respect and reverence. A strong twist is found in Le Gobien's Histoire (1700: 49) in which he divided CHamoru society into three rigid states: the nobility, the common people, and the people of a medium condition. Le Gobien, who never set foot in the Marianas, based his Histoire on previous documents. He converted lineages into social states, most probably reflecting the rigid Old Regime three-state society he belonged to (see also Russell 1998: 143). Even so, Le Gobien (1700: 51) also copied the idea that principales did not have real power. In his 1719 Annual Letter from Rota, Jesuit Joseph Bonani (1719: 7) also mentioned three social castes: the matóa, the acháot and the mangachang (also see Russell 1998: 142). With slight changes, this was the social division recorded by Freycinet (1829: 364) in the nineteenth century, and accepted by some twentieth-century scholars (for instance, Thompson 1945: 13).

Documents from the seventeenth century also noted rivalries between the different villages. Pobre de Zamora was the first to notice social deference manifested by the mangachanes - or inland villagers - towards the coastal inhabitants, who were portrayed as more important and as controlling access to the coast (Martínez 1997: 448). The principals were, notwithstanding, also reported as existing inland (García 1683: 153). In any case, documents also made it very clear that there was no single inter- or intra-island political authority (García 1683: 201-202; Ledesma 1670: fol. 3; Martínez 1997: 446).

According to the sources, most principales would have been men, although the presence of female peers is occasionally recorded (García 1683: 205, 577-578; Lévesque 2000: 18). It may be possible that the Jesuits did not notice magahagas, the women in chief positions. However, the fact that they did notice and report some, as well as a number of situations — such as marital disputes (Aranda 1690: 217-218; Lévesque 2000: 18; García 1683: 447; Martínez 1997: 447)—that they interpreted as events where women enjoyed more power and privilege may give credence to the fact that most principales were men.

Referring to the division of labor, the texts report that some tasks were shared and others divided between men and women in a complementary fashion. Women would cook and plantweave (Martínez 1997: 444) while men would take charge of deep-sea fishing (Martínez 1997: 442). Jesuit Peter Coomans, however, also noticed, with surprise and admiration in equal measure, women's dexterity in boat handling (Lévesque 2000: 13). Both women and men would cultivate their lands, fish in the lagoon, and teach their children the activities they would be expected to know (Martínez 1997: 444). Communal cooperative tasks such as building houses (Martínez 1997: 445) or providing for the sick are also described, as are feasting banquets and celebrations that gathered different villages where dancing, chanting, and what seem to be ritualized male contests took place (Martínez 1997: 445, 446, 450). Likewise, specific female festivities are also noted (Ledesma 1670: 3v). 
Another activity consistently appearing in the written records is the food-for-iron exchange with European vessels. Although other items were also exchanged, iron seems to have been prominent in Native demands. Unfortunately, we have less than full information about its uses. Nevertheless, it seems mainly to have been employed for manufacturing fish hooks and tools such as knives and adzes to work the wood used in canoe- and house-building (Martínez 1997: 442, 443, 448; Lévesque 1995a: 479), shaving the body (Lévesque 1995a: 321), and working the fields to sow rice and some vegetables (Donoso 2016: 4-5; Ribadeneira 1601: 85; and see also Quimby 2011). Importantly, it is said that urritaos (bachelors) used iron to buy or rent women from their parents while the men were in what the Jesuits called "public houses" (García 1683: 201).

\section{Latte Communities in the Archaeological Record}

Most archaeological efforts in Guam have concentrated on the Latte period. Even so, multiple questions await further investigation, such as the meaning of the significant size differences in Latte buildings, the most iconic element in Marianas' archaeology. Stone pillars may measure from $50 \mathrm{~cm}$ to $5 \mathrm{~m}$ in height. They are paired in rows that average from 3 to $6 \mathrm{~m}$ in length (Carson 2016: 233). Latte buildings clearly varied in size. Roughly speaking, however, the same material culture has been documented in most of them, although sometimes in different proportions (Bayman et al. 2012; Bayman and Peterson 2016).

Archaeological excavations and surveys (Graves et al. 1990; Moore 2012; Russell 1998) have recorded a series of artifacts, some described and others unmentioned by the sources. In the first category, we can find hooks of different materials (including iron), stone adzes, sling stones, and human bone tools. Pottery and lusong grinding stones figure in the second category. Features like paving, debris accumulation, post holes, hearths, and earth ovens have also been documented (Bulgrin 2006; Dixon et al. 2006; Moore 2005), as well as evidence of swidden farming, household gardening, jungle harvesting, shellfish gathering, and lagoon and pelagic fishing (Carson 2012; Dixon et al. 2011; Manner 2008).

Pit burials have been found below and in the immediate vicinity of Latte buildings, making it clear that Latte CHamorus frequently used spaces inhabited by the living to bury their dead. Not everything was, however, orthodox Latte in the Latte period since caves and rock shelters also served as domestic spaces and burial grounds (Dixon and Schaefer 2014). Although more comprehensive archaeological mortuary studies are needed, at the moment, no significant sex disparities regarding funerary practices or the presence of sex-exclusive grave-goods have been published (Stodder et al. 2015; Walth 2016, p. 341). Although women at Naton Beach displayed more beads than men (Amesbury et al. 2020), both groups wore beads; and both were buried with sling-stones and adzes at this same site (Walth 2016: 341). The sources state that these materials belonged to men and "principales" respectively (Martínez 1997: 468). Many burials, however, featured no grave goods at all. In addition, only some adult skeletons (both female and male) 
displayed dental modifications (Heathcote et al. 2012: 147; Ikehara-Quebral and Douglas 1997; Pietrusewsky et al. 2014: 329; Stodder et al. 2015: 532; Thompson 1945: 10).

Skeletons deprived of their skulls and diaphyses have also been recovered (McNeill 2005: 314; Walth 2016: 354), as have isolated skulls in burials (McNeill 2005: 309). These findings are consistent with the use of human bone, related by the Spanish sources, to manufacture tools (Lévesque 2000: 25; García 1683: 200) and worship the skulls of the ancestors (de Aranda 1690: 220; Lévesque 2000: 17; Martínez 1997:448-449; and see Driver 1983). The findings are also consistent with the Jesuit's forced reburials of these skulls that were mentioned by the same sources (García 1683: 408; and see Montón-Subías et al. 2020: 66).

\section{Change and Continuity in Latte Societies}

Conflating archaeological and European textual information, it appears that Latte societies exhibited complete orality (thus no writing, and no or few abstract representations of reality and scientific explanations of nature's mechanics), and no clear social stratification. They were also characterized by the performance of recurrent tasks driven by horticulture and household gardening, lagoon and deep-sea fishing, shellfish gathering, jungle foraging, and maintenance activities. In such a situation, it is possible to assume a perception of reality mediated by mythical explanations, with importance given to ancestors and tradition (as emphasized by the sources here and there), and by an absence of a deliberate search for change. This is the case in oral societies with similar features (Clastres 2014; Hernando 2002, 2018; Ong 1982). It is probably true for the Latte CHamorus as well because, among other reasons, most of their daily activities were governed by recurrence and lack of functional fragmentation, generating the same recurring perception of other aspects of reality. It is possible that there were ranked lineages, none of them prevailing over or controlling the others. The idea that these lineages were of matrilineal descent is a deep-seated belief in today's Marianas (Atienza and Coello 2012; Bayman et al. 2012; Bayman and Peterson 2016; Hunter-Anderson 2011; Hunter-Anderson and Butler 1995; Perez Hattori 2018; Peterson 2012; Souder 1992; Thompson 1945). While more investigation is required to understand the actual social implications of such matrilineal kinship, it is still compelling to contemplate a society with less gender asymmetry than during the colony (Montón-Subías 2019).

Although Michael Graves (1986) argued that the different sizes of Latte buildings indicated social stratification, such disparities have been most frequently interpreted as resulting from different functions (as the sources say) or architectonic traditions. As already emphasized by Cordy (1983), the span of the early documents posits lineages of different statuses, not social classes. Most archaeologists of the Marianas' prehistory subscribe to horizontal, not vertical, social organization (Craib 1986; Dixon et al. 2006: 56; Hunter-Anderson and Butler 1995; Laguana et al. 2012: 87; Peterson 2012: 202-203; Russell 1998: 139-151; Stodder et al. 2015). Following classical anthropology (Clastres 2014: 111-116), the principales could have been 
chiefs or community leaders without real power over their communities (see also Driver 1983: 208).

Interactions with Spanish Manila galleons and other European vessels no doubt impacted Latte CHamorus. Rodrigue Lévesque (1992b: 653-655; 1995a: 687-690) found that about 180 vessels landed in Guam during the protacted period spanning 1521 to 1668 (1992a, 1993, 1995a). Since iron was associated with prestige and social transactions in CHamoru society, Frank Quimby (2011: 16) noticed that such trade "may have intensified indigenous dynamics, including social differentiation." Repercussions in land use, agriculture, and fish weirs to meet galleons' provisioning demands have also been compellingly argued (Dixon et al. 2010, 2020: 68).

It is within this social scenario that we must situate CHamoru attitudes towards change and continuity, as well as the desire to incorporate iron and accept castaways. These actions were possibly directed by principales - though not, in this case, out of any intrinsic taste for cultural innovation, creativity and cosmopolitanism on the part of the elite (Quimby 2011: 25). Once technological innovations are incorporated, they have effects in the community; or more precisely, on persons or groups within the community who use these innovations. This increases their sense of technological control, which in turn will lead them to seek more changes, augmenting their feeling of difference.

Likewise, the gender variable must also be considered when analyzing the dynamics of social change and continuity. If we posit that those with more power or privilege will adopt a greater tendency to change, and power or privilege is gender sensitive, then gender differences will emerge or be aggravated. In the case of CHamoru Latte societies, where differences in work specialization between the genders were not great, women and men might have shared quite similar attitudes toward change and continuity, with the possible exception of the principales. Unfortunately, the endogenous CHamoru historical pathway was truncated by the Jesuit mission, and we cannot know with certainty what would have happened without the Jesuits. We do know, however, that colonialism promoted social difference between men and women (Souder 1992) and the increasing association of women with tasks, such as maintenance activities, that were expressive of continuities (Montón-Subías 2019).

\section{Missions and Reducciones}

Coinciding with increasing critiques of illicit enrichment and corruption in their order, the Jesuits started their first mission in the Marianas in 1668. Nothing served their purpose better than a bunch of lonesome islands featuring no "diamonds, fragrances, pearls, nor gold" (García 1683: 244), only richness in "poor souls" (García 1683: 143, 170). This served to offset the charges laid against them and show the world their true religious vocation. Their initial welcome on Guam soon turned to hostility and open resistance by those CHamorus having no desire to follow Christian guidelines developed abroad. Diego Luis de Sanvitores subsequently dropped what were initially peaceful intentions and requested military support from the Crown. Such support was instrumental in implementing La Reducción, a process 
by which native CHamorus were forcibly uprooted from their ancestral lands and nucleated into a reduced number of villages or towns (Driver 1988).

Various studies of the Marianas have emphasized the changes that occurred during La Reducción (Bayman and Peterson 2016; Montón-Subías 2019; Montón-Subías and Moral de Eusebio 2021; Peña 2020; Russell 1998: 317-322). Indeed, the missions on Guam brought about abrupt and profound changes, as did modern colonialism in the rest of the world. The reducciones were not only administrative centers serving to control mobility and avoid uprisings. They functioned as true "civilization" centers where the settled quotidian routines were changed into new ones. New corporeal disciplines (sensu Foucault 1975) related to food, health, body care, dress, and sexuality were imposed, as well as new labor regimes, kinship systems, land-tenure patterns, and Native land dispossessions, among other things.

There can be no doubt that colonization impacted the CHamoru social structure, creating new intersections of social, economic, and racial inequality. Gender was part of this changing social structure. Political offices were, for instance, only given to male CHamorus who were considered loyal to the Crown, which promoted male hierarchy (Perez Hattori 2018: 175; Souder 1992: 76). Local institutions were forbidden while new ones were installed. The destruction and substitution of the socalled guma'uritaos, or bachelor houses, by formal schools where indissoluble marriage and nuclear monogamous families were promoted, is a telling example (Moral de Eusebio 2016). Perhaps the most conspicuous physical correlate of the social unrest that ensued is to be found in the plummeting population that even endangered the very continuity of the colony (Hezel 2015: 80-81).

CHamoru Latte subjectivities must have been affected in the process. Interactions between CHamorus and missionaries constituted a clear example of acute cultural distance. The two groups exhibited very different ways-almost as different as possible at that moment - of understanding and ordering the world. Alongside scientists, Jesuits occupied the highest levels of logocentrism, self-reflection (Molina 2013), and individualization at that time. These features are all connected to the hierarchic binary thinking that subordinates the body, animals, and nature to mind, humans and culture; and women to men, with simultaneous efforts to eliminate possible others. Through the disciplines of reading and writing, for instance, mission schools converted oral CHamoru children into literate children, thereby promoting abstract thinking, self-objectification, and identification with Jesuit subjectivities, values, and worldviews in all those who attended the schools. Sixteenth- and seventeenth-century documents are full of references to the concrete way of thinking of oral native CHamorus. Striking examples are Jesuit complaints about literal understandings of Christian religion (Ribadeneira 1601: 87), counting systems adapted to what is being counted (Kerr 2013: 5), and CHamoru personal names linked to nature or the person's behavior. Juan Pobre de Zamora even reports that he was named "Dios" (God) by CHamorus, emulating the expression "Dios, Dios" that he employed frequently (Martínez 1997: 424). We can therefore imagine how awkward Christian names received after baptism would feel to CHamorus, who could find no meaning in them.

Missionization also brought a fundamental change in the perception of time. The emergence of time as something countable, measurable, externalized, capable of 
possession, and even potentially productive became part of the process. In Europe, the first public clocks came into use in the fourteenth century. They were placed in church towers by public markets with a clear functional intent (Thompson 1970: 63). It is precisely this functionality that Jesuits incorporated into CHamoru communities as part of their colonial discipline. Jesuit documents, for example, praised punctuality as well as time distribution and maximization at schools, where the disciplines of abstract time and counting were introduced; and which obliged children to wake up early to attend classes (García 1683: 240; Lévesque 1995b: 142). From then on, as in Europe, time would be scheduled not only by nature but by church bells (Díaz 1994: 43; Russell 1998: 317). Abundant references to native "vagrancy" in the written records, however, may indicate that the new temporal patterns were not accepted to the extent desired, and can be interpreted as acts of CHamoru resistance. Indeed, resistance and persistence both obtained in the colony. Illustrations and written documents from the eighteenth and nineteenth centuries describe some uses and customs that bear more witness to cultural continuities than a too-literal reading of seventhcentury sources would suggest. These uses and customs can be understood as acts of cultural reaffirmation in response to outside imposition, and as assertions made by CHamoru communities to escape cultural dissolution. As in other areas of the new colonial world, resistance was very often expressed in a determined effort to maintain one's own traditional personal appearance, activities and tasks.

A range of scholars from a variety of viewpoints have noticed cultural persistence in Guam (Atienza 2019; Clement 2019; Diaz 1994; Leon Guerrero 2019; Lujan Bevacqua 2020; Na'puti and Lujan Bevacqua 2015; Perez Hattori 2007; Perez Viernes 2016; Souder 1992). A new avenue of archaeological research is also investigating the topic in archaeological sites such as lånchos, ranch-type farms that remained beyond immediate colonial surveillance (Bayman et al. 2020; Dixon et al. 2020). We will focus in this article, however, on cultural persistence within the very reducciones themselves, using material culture, maintenance activities, and textile manufacture as case examples.

\section{Cultural Persistence and Maintenance Activities}

We contend that cultural persistence is more easily found in those activities and in those persons that, despite being affected by changes, are less or not at all involved in full-time specialization and therefore in processes of individualization that will in turn promote a positive appraisal of change. Maintenance Activities are a most suitable domain to search for cultural continuities.

Maintenance Activities is a concept that highlights the structural role of all those tasks of everyday living that are: (a) repetitive, recurrent, and routine; (b) essential to social reproduction and well-being; and (c) performed in the same known spaces, usually within the bounds of the house, the settlement, or its immediate vicinity. As noted previously, they include (but are not limited to) basic cooking, basic textile manufacture, basic hygiene, health and healing, children's socialization and rearing, the provision of care, and the arrangement of living spaces. They may take on different forms according to geography and chronology, but they always cement a 
group's cohesion through the strengthening of basic bonds. Their structuring role guarantees the recurrence of the group's activities and/or the channeling of changes into new recurrence patterns that reinstate basic stability and permit social continuity (González Marcén et al. 2008).

By dint of being structurally aimed at communal well-being and at bolstering the group's sense of cohesion, their performance fosters a particular type of personal identity where the self is understood in relation to others. They are thus very different from activities associated with individuality and social power (Hernando 2008; Montón-Subías 2010). While always fundamental, their social value is nevertheless less recognized the greater the social asymmetries are. In such situations, they are usually performed by those enjoying less social power (usually women in the historical and ethnographic record).

Importantly, the specific knowledge sets, techniques, and skills required by maintenance activities can sometimes be used by the same persons for purposes that surpass maintenance activities. Plant-weaving is a clear example.

\section{Plaiting as Cultural Continuity}

Coconut and pandanus leaf-weaving is now considered "one of the lasting artistries of Chamoru culture" (Anderson-Taft 2019). Master weavers of the present treasure an ancestral knowledge that they share with all those willing to learn it (Auyong 2019; Flores 2019; Tolentino 2019). We were shown parts of the process at Gef Pa'go Cultural Village (Inålahan), where traditional arts, crafts, and cooking are demonstrated to visitors. Although plaiting and its products are less prevalent today than in the past (when plaiting laid at the core of CHamoru daily life), and although they are now situated within a different historical and social context, they remain a clear example of resilience in Indigenous material practices.

Pre-Reducción documents referred to plaiting as one of the finest industries of the archipelago and as women's work. Inspired by twentieth-century ethnographies, we believe it is justified to assume that the savoir faire involved in plant weavingknowledge of a plant's characteristics, the optimal time for harvest, techniques to work the leaves, and piece manufacturing (Anderson-Taft 2019; Flores 2019; Tolentino 2019) — was shared and transmitted by most Latte CHamoru women. These twentieth-century ethnographies show that most women and most men are able to perform the tasks assigned to their gender when division of labor takes place only according to gender (Clastres 2014: 201), as must have occurred in CHamoru Latte societies. It also seems plausible to assume that the entire process-from planting to harvesting to the final product-remained in the same hands. Unfortunately, no specific information is given about how plaited artifacts were made (i.e., how materials were gathered, prepared, and woven together into the different forms), but even so we have broad information regarding their varied uses.

Juan Pobre de Zamora indicated that palm and nipay leaves were employed to make mats for domestic and funerary equipment including mattresses and blankets, tables to serve food, boxes for the ancestors' skulls, shrouds for the deceased, and tomb covers. These leaves were also used for sending presents, making hats in 
different styles, and fashioning small baskets to carry betel nuts (Martínez 1997: $444,447-448,451)$. Other sixteenth-century sources mention plaited baskets to carry sling stones (Kerr 2013: 389) and plaited sails (Kerr 2013: 388; Donoso 2016, pp. 2-3), and they illustrate some of their functions (du Nort 1602: 34). All these uses are confirmed by seventeenth-century colonial sources which also record other functions: for houses, curtains, and wall covers (Lévesque 1995b: 124); for sandals (Lévesque 1995b: 39, 1995c: 429); for baby cradles, plates to serve food, and even armor (Lévesque 2000: 12, 27); and for funerals, small baskets to gather the soul of the recently departed, and bows and triumphal arches to ornament the streets when the deceased was a principal (Sanvitores et al. 1671: 125). Moreover, plaiting techniques were employed to roof CHamoru thatched houses. Sources from that period state only that the building and repair of houses were collective efforts (Martínez 1997: 445), but documents from the nineteenth century (Freycinet 1829: 320; Craig 1982: 15) describe these as male activities, with women engaged in cooking for the subsequent fiesta (celebration). However, twentieth-century photographs show walls and roof-thatch plaiting as women's work (Thompson 1947: 66, 268) (see Fig. 6). This seems to accord with the allocation of plaiting to women mentioned in sixteenth- and seventeenth-century sources. Finally, although the CHamoru people of precolonial times did not use textiles to dress their bodies (Montón-Subías and Moral de Eusebio 2021), the few recorded exceptions in the written record-some of the women's tifis to cover their pubic areas and female palm skirts usually worn in festivals-were also plant-weaved. Plaited goods were also used for social transactions and exchange. Sources mention at least two such events. One refers to women's dowries, which included a small well-crafted palm mat (Lévesque 1995a, 1995b: 322). The other relates to exchanges with European vessels before the colony, and to the fact that palm mats figured among the CHamoru commodities, together with food supplies (Ribadeneira 1601: 84). The Boxer Code (Donoso 2016: 4-5) even records an episode in which palm mats are added to other trade goods to make the offer more attractive.

Many of these items and uses survived through La Reducción, and coexisted with the new weaving techniques, all of which related to cotton textile manufacture, that the Jesuits introduced. For instance, the seventeenth-century Annual Letters mention that girls continued plaiting traditional mats at schools (Bustillo 1690) in addition to learning how to spindle and sew. Exploration expeditions of the eighteenth and nineteenth centuries, while staying in the Marianas, also recorded and illustrated many of them. In 1819, for instance, the Freycinet (1829: 317-318) expedition included the CHamoru names of various artifacts. A few examples are alan mamaon (boxes for betel nuts), téfan (floor mats), sarghi (a tray for cooked rice), and lä̈man (a mat where fish and other commodities are left to dry-see also Flores 2019). Freycinet even noticed objects that had recently been abandoned, such as plaited cradles (fagapsan) and baskets to carry babies (aktø). He also noted others that coexisted with more recent goods made of cloth and leather, for example hats, and sandals used for fishing and walking on the reef (Freycinet 1829 308-309; Fig. 8).

Some nineteenth-century objects, such as those curated in Madrid, have survived until the present including fans, bags, sandals, baskets, and mats (see Figs. 2, 3, and 4). These objects were first exhibited in 1887, in the Exposición General de 


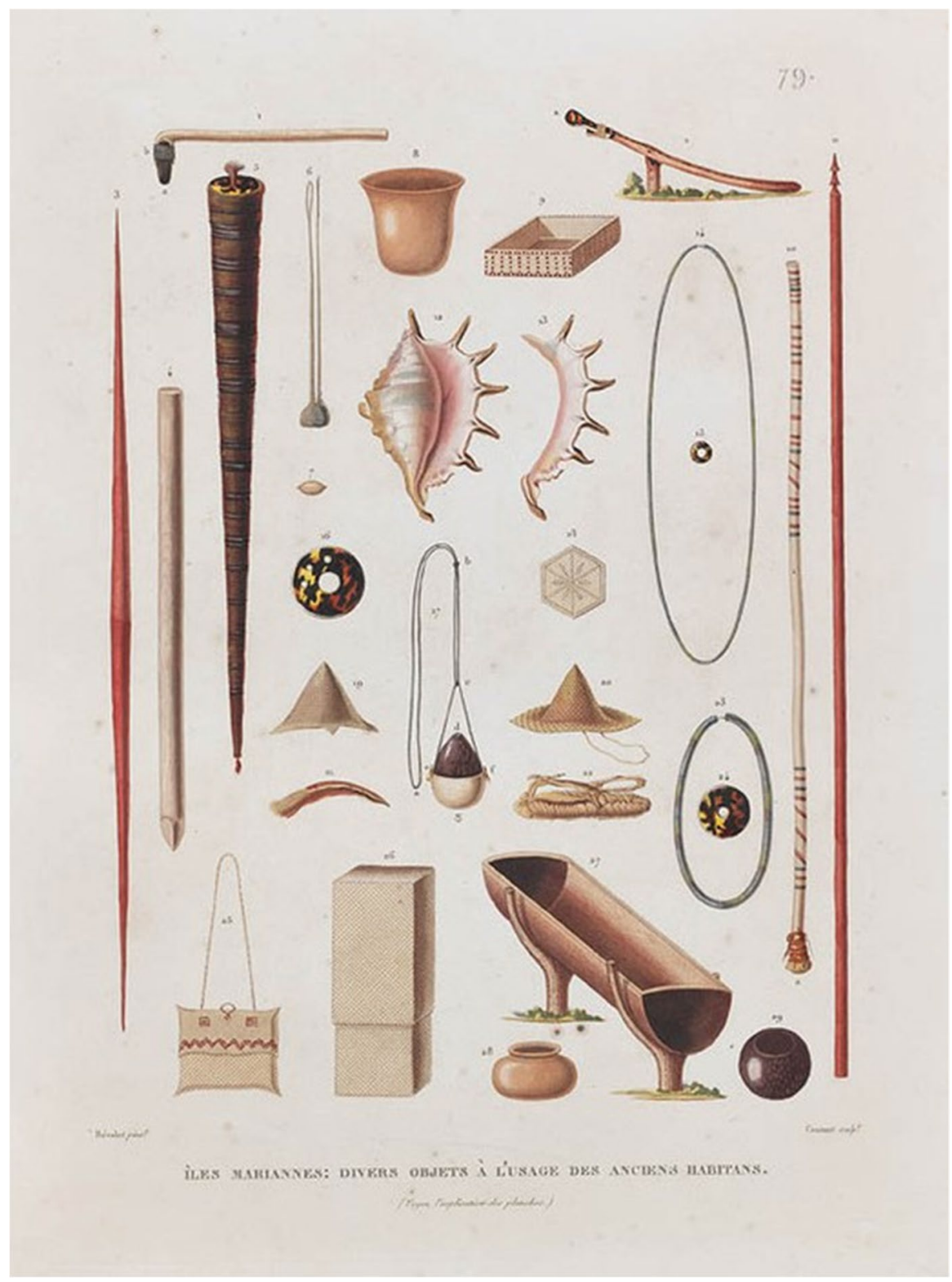

Fig. 8 Different objects from the Marianas recorded by the Freycinet expedition (Freycinet 1829). From the collections of the State Library of New South Wales

las Islas Filipinas (General Exhibition of the Philippine Islands) that took place in Madrid when the Marianas were still a Spanish colony. They were crafted upon request (Alonso 2021). Some of them clearly show the same diagonal plaiting patterns as those depicted in 1600 (see Fig. 5). Unfortunately, we lack textile products 
with previous chronologies. The presence, however, of manufacturing tools may have survived archaeologically, a possibility to be investigated. Although human hands are the main tools employed in plaiting, Judith Flores (1999: 64, 122) mentions that nowadays a triangular tool-the $s i$ ' $i$-is used in the process, as well as needles in the making of roof thatch. These tools are now made of metal but were previously fabricated from bamboo or shell. Photographs from the twentieth century and oral history bear witness to the protracted use of plaiting in pre-war Guam and even in the immediate postwar years (Auyong 2019; Tolentino 2019; Thompson 1947; see Fig. 6). The 1950s, however, saw the replacement of traditional materials by imported ones, such as concrete and plastic, and a subsequent decrease in plaited objects along with the number of islanders with the skills to produce them (Anderson-Taft 2019; Auyong 2019). Freycinet recorded (1829: 320) that all women plaited, regardless of social class. However, by the prewar twentieth century and according to Laura Thompson (1947: 159), only some women were specialists in the craft, demonstrating it was no longer performed by all of them (for an interesting parallel, see Brumfiel 2006: 869).

According to Farrell (2011: 189-190), women at the reducciones were forced to weave sleeping mats and sails which were later exported to the Philippines, another Spanish colony at that time. Two centuries later, master weaver Lucia Fernandez Torres recounted that both she and her brother were obliged to weave baskets under Japanese colonial rule (Flores 2019). In between, plaited artifacts were apparently used to pay taxes during the first period of US rule. In this time period, plaiting was taught to girls at rural schools to encourage manufacture and export (Thompson 1947: 117, 257). Other twentieth-century testimonies report male plaiting. For instance, master weaver Floren Paulino learned the skill from her father (Tolentino 2019). She was born in 1925, which makes us suspect some men could have known how to weave in the very early twentieth century (see also Flores 1999: 124). We do not know if this ability among men extended further into the past.

\section{Discussion and Conclusions}

Indigenous rights activists have thwarted in Marianas narratives of CHamoru cultural demise and led the defense of cultural resistance and revitalization (Clement 2019; Diaz 1994; Leon Guerrero 2019; Lujan Bevacqua and Kelly Bowman 2016; Lujan Bevacqua 2020; Na'puti and Lujan Bevacqua 2015; Perez Hattori 2007, 2018; Perez Viernes 2016; Souder 1992; https://500sails.org/). The reinvigorating of tradition and the connection and reconnection with precolonial material culture as part of that effort have been at the core of such a movement. Archaeology in Guam has recently joined the search for cultural continuities through studies of lanchos. In this article, we have focused on the reducciones, maintenance activities, and plaiting in the course of acknowledging processes of CHamoru cultural resilience while at the same time highlighting the traumatic consequences, past and present, of modern colonialism. Cultural persistence existed but it cannot be used to soften or whitewash the violent nature of colonialism. 
In the particular case that brings us here, it is rather curious that while the Jesuits exposed and condemned abuses perpetrated by other colonial agents, such as governors and the militia, they themselves were the ones who most comprehensively targeted the soul of CHamoru traditional lifeways and cultural logic. If we bear in mind the role that tradition plays in oral societies, where it is perceived as the key to a group's very survival, we will fully understand the magnitude of the colonialist policies practiced by the Jesuits upon the Latte people. Even so, various precolonial practices, both tangible and intangible, resisted and persisted through the changing world of La Reducción.

As in other regions of the world, the role of women in preserving such traditions has been highlighted for Guam (Farrell 2011: 191; Leon Guerrero 2019; Souder 1992; Taitano DeLeslie 2015). Far from grounding the quest for continuity in an allegedly female nature, we believe this common association-namely, women and continuity - is explained by women's engagement in chores that do not imply functional specialization and work fragmentation. These chores entail and require selfperception as part of a broader group and thus relational identity. For this reason they are structurally associated to community building. This was the case with plaiting during the Latte and the modern colonial period in Guam. Needless to say, cultural continuities will be found not only here, but in all those realms that express relational identity and group belonging.

The example of Guam also speaks to the progressive identification of maintenance activities with women's work during modern colonization, and the associated loss of social recognition. The aforementioned attitudes towards change and continuity in different types of societies apply to people in a single society when socioeconomic differentiation (which colonialism promoted in Guam and elsewhere) ranks high. Those further away from social positions of power and tasks increasingly affected by functional fragmentation and rapid technological innovation will maintain high esteem for continuity and tradition. This is because the activities for which they are responsible will continue to require and promote identification with the group as a whole and thus self-construction in a more relational, less individualistic way. It is important to note that we are not saying that maintenance activities and plaiting never change or that those who perform them lack technological skills and knowledge. What we are emphasizing is that the transformation of these activities is less accelerated and intense than are practices related to individualism and social power.

Through plaiting within reducciones, women nurtured the connection with their ancestral traditions, both for themselves personally and for the entire group. At a time when such traditions were under siege and in many cases disrupted, this was of the utmost importance. The manufacture and use of plaited material culture surely helped mitigate profound ontological disorientation after the forced relocation from ancestral lands. As in other areas of the globe (for instance, Federicci 2004: 299), missional attacks on Native traditions in Guam targeted the community as a whole, its historical roots, and its spiritual relationship with the land, territory, and nature. By the same token, however, we can assume that traditions surviving the assault defended and still defend those vital things. 
CHamoru plaiting has persisted through distinct historical contexts and has served diverse purposes through the centuries. No doubt Latte manufacture of daily household equipment was different than the manufactures requested under Spanish, Japanese, and American colonial mandates. Still, plaiting to serve the basic needs of the household coexisted with all these imperial (ab)uses. It must have been crucial to saving and adjusting tradition inside the reducciones, moving from one generation to the next in unison with an intangible heritage. At some point in recent history, women's shared knowledge of plaiting concentrated into fewer hands, but the generalized use of plaited objects must nevertheless have helped preserve a sense of connection to the past. The postwar arrival of materials from abroad impacted plaited artifacts, diminishing their use. Yet plaiting has survived to the present. Today, it is vindicated as Kostumbren CHamoru (see https://www.guampedia.com/ voices-of-our-elders/), a rubric to refer to traditional relational values and practices, express CHamoru identity, and defend cultural continuity.

Acknowledgments This article was written with the support of the Spanish Ministry of Science and Innovation under Grant PID2019-105431GB-I00.

Funding Open Access funding provided thanks to the CRUE-CSIC agreement with Springer Nature.

Open Access This article is licensed under a Creative Commons Attribution 4.0 International License, which permits use, sharing, adaptation, distribution and reproduction in any medium or format, as long as you give appropriate credit to the original author(s) and the source, provide a link to the Creative Commons licence, and indicate if changes were made. The images or other third party material in this article are included in the article's Creative Commons licence, unless indicated otherwise in a credit line to the material. If material is not included in the article's Creative Commons licence and your intended use is not permitted by statutory regulation or exceeds the permitted use, you will need to obtain permission directly from the copyright holder. To view a copy of this licence, visit http://creativecommons.org/licen ses/by/4.0/.

\section{References}

Alonso, P. (2021). The Mariana Islands Collections in the Museo Nacional de Antropología (MNA) and the 1887 Philippine Exhibition. In Alonso, P. and Jiménez, M. J. (eds.), I estoria-ta: Guam, Marianas y la Cultura Chamorra. Ministerio de Cultura y Deporte y Acción Cultural Española, Madrid.

Amesbury, J., Walth, C., and Bayman, J. (2020). Marine shell ornaments and the political economy of gendered power in the Mariana Islands. Journal of Island and Coastal Archaeology 15(4). https:// doi.org/10.1080/15564894.2020.1838972.

Anderson-Taft, T. J. (2019). Weaving. https://www.guampedia.com/weaving/; accessed May 2020.

Appadurai, A. (1990). Disjuncture and difference in the global cultural economy. Public Culture 2: 1-24.

Aranda, G. (1690). Vida y Gloriosa Muerte del Venerable Padre Sebastián de Monroy. Thomas López de Haro, Sevilla.

Ardener, E. (2012). Remote areas: some theoretical considerations. HAU: Journal of Ethnographic Theory 2(1): 519-533.

Atalay, S. (2006). No sense of the struggle: creating a context for survivance at the NMAI. American Indian Quarterly 30(3 and 4): 597-618.

Atienza, D. (2019). CHamoru "Adaptive resistance" during the Spanish conquest and colonization of the Marianas Islands. Fourth Marianas History Conference, Guampedia, Manguilao, pp. 3-15.

Atienza, D. and Coello, A. (2012). Death rituals and identity in contemporary Guam (Mariana Islands). The Journal of Pacific History 47(4): 459-473. 
Auyong, M. A. (2019). Elena Cruz Benavente. https://www.guampedia.com/elena-cruz-benavente/; accessed May 2020.

Bayman, J. and Peterson, J. (2016). Spanish colonial history and archaeology in the Mariana Islands: echoes from the western Pacific. In Montón-Subías, S., Cruz Berrocal, M., and Ruiz, A. (eds.), Archaeologies of Early Modern Spanish Colonialism, Springer, New York, pp. 229-252.

Bayman, J., Kurashina, H., Carson, M., Peterson, J., Doig, D., and Drengson, J. (2012). Household economy and gendered labor in the 17th century AD in the Mariana Islands, western Pacific. Journal of Field Archaeology 37: 259-269.

Bayman, J., Dixon, B., Montón-Subías, S., and Moragas, N. (2020). Colonial surveillance, Låncho, and the perpetuation of intangible cultural heritage in Guam, Mariana Islands. In Beaule, C. and Douglass, J. (eds.), The Global Spanish Empire: Five Hundred Years of Place Making and Pluralism. University of Arizona Press, Tucson, pp. 222-241.

Bonani, J. (1719). Geßchrieben auf der Marianißchen Inßul Rota. In Stöcklein, J., Probst, P., and Keller, F. (eds.), Allerhand so Lehr-als Geist-reiche Brief. Gratz, Augspurg.

Bustillo, L. (1690). Relación del estado y progresos de la misión de las Islas Marianas desde mayo pasado de 89 hasta el de 90 (Account of the status and progress of the misión of the Mariana Islands from last May of 89 to that of 90), 23 May. 75r-82v, 14, Philipp, Archivum Romanum Societatis Iesu, Rome, Italy.

Brumfiel, E. (2006). Cloth, gender, continuity, and change: fabricating unity in anthropology. American Anthropologist 108(4): 862-877.

Bulgrin, L. (2006). Fina'okso' Antigu: prehistoric soil mounds in the interior of Rota. Micronesian Journal of the Humanities and Social Sciences 5(1/2): 31-41.

Carson, M. (2012). An overview of latte period archaeology. Micronesica 42(1/2): 1-79.

Carson, M. (2016). A sea of islands and monuments. In Carson, M. (ed.), Archaeological Landscape Evolution. Springer, NY, pp. 221-257.

Clastres, P. (2014). Investigaciones en Antropología Política. Gedisa, Barcelona.

Clement, M. (2019). Garrison folks and reducciones: bifurcating the Hagåtña narrative in 18th century Marianas history. 4th Marianas History Conference, Guampedia, Manguilao, pp. 27-58.

Clossey, L. (2006). Merchants, migrants, missionaries, and globalization in the early-modern Pacific. Journal of Global History 1: 41-58.

Coello, A. (2016). Jesuits at the Margins: Missions and Missionaries in the Mariana Islands (16681769). Routledge, London.

Colomer, L., González Marcén, P., and Montón Subías, S. (1998). Maintenance activities, technological knowledge and consumption patterns: a view of northeast Iberia (2000-500 Cal BC). Journal of Mediterranean Archaeology 11: 53-80.

Cordy, R. (1983). Social stratification in the Mariana Islands. Oceania 53: 272-276.

Craib, J. (1986). Casas de los Antiguos: Social Differentiation in Protohistoric CHamoru Society. Doctoral dissertation, University of Sydney, Sydney.

Craig, R. D. (ed.) (1982). The Mariana Islands: A Report by Antoine-Alfred Marche 1887. Micronesian Area Research Center, Manguilao.

Deagan, K. (2004). Reconsidering Taíno social dynamics after Spanish conquest: gender and class in culture contact studies. American Antiquity 69(4): 597-626.

Diaz, V. M. (1994). Simply CHamoru: telling tales of demise and survival in Guam. Contemporary Pacific 6(1): 29-58.

Dixon, B. and Schaefer, R. (2014). Archaeological investigation of caves and rock shelters on Guam and Tinian: a synthesis of their use through time. Journal of Pacific Archaeology 5(1): 52-71.

Dixon, B., Mangieri, T., McDowell, E., Paraso, K., and Rieth, T. (2006). Prehistoric CHamoru household activities and refuse disposal patterns on the Micronesian Island of Tinian, Commonwealth of the Northern Mariana Islands. Micronesica 31(1): 55-71.

Dixon, B., Schaefer, R., and McCurdy, T. (2010). Traditional CHamoru farming innovations during the Spanish and Philippine contact period on northern Guam. Philippine Quarterly of Culture and Society 38(4): 291-321.

Dixon, B., Barton, H., Coil, J., Dickinson, W., Murakami, G., and Ward, J. (2011). Recognizing inland expansion of Latte period agriculture from multi-disciplinary data on Tinian, Commonwealth of the Northern Mariana Islands. Journal of Island and Coastal Archaeology 6: 375-397.

Dixon, B., Welch, D., and Bulgrin, L. (2020). Archaeological roots of traditional land use and resistance to Spanish colonial engagement on Guam. Asian Perspectives 59(1): 61-99. 
Donoso, I. (ed.) (2016). Boxer Codex: A Modern Spanish Transcription and English Translation of 16thCentury Exploration Accounts of East and Southeast Asia and the Pacific. Vibal Foundation, Ciudad Quezón.

Driver, M. (1983). Fray Juan Pobre de Zamora and his account of the Mariana Islands. Journal of Pacific History 18(3): 198-216.

Driver, M. (1988). Cross, sword, and silver: the nascent Spanish colony in the Mariana Islands. Pacific Studies 11(3): 21-51.

Driver, M. (1990). Changing maritime activities in the Mariana Islands 1521-1821, Magellan to Medinilla. Journal of the Pacific Society 94: 1-4.

du Nort, O. (1602). Description du Penible Voyage faict Entour de L'univers ou Globe Terrestre. Chez Cornille, Amsterdam.

Eliade, M. (1959). The Sacred and the Profane: The Nature of Religion. Harcourt, Brace and World, New York.

Elias, N. (1987). Involvement and Detachment: Contributions to the Sociology of Knowledge. Blackwell, Oxford.

Elias, N. (2000). The Civilizing Process: Sociogenetic and Psychogenetic investigations. Blackwell, Oxford.

Fanon, F. (1961). Les Damnés de la Terre. Éditions Maspero, Paris.

Farrell, D. A. (2011). History of the Mariana Islands to Partition. Public School System, CNMI, Saipan.

Federicci, S. (2004). Calibán y la Bruja: Mujeres, Cuerpo y Acumulación Originaria. Traficantes de Sueños, Madrid.

Flexner, J. (2014). Historical Archaeology, Contact, and Colonialism in Oceania. Journal of Archaeological Research 22: 43-87.

Flores, J. (1999). Art and Identity in the Mariana Islands: Issues of Reconstructing an Ancient Past. Doctoral dissertation, Sainsbury Centre for the Visual Arts of Africa, the Americas and Oceania, University of East Anglia, Norwich.

Flores, J. (2019). Lucia Fernandez Torres. https://www.guampedia.com/lucia-fernandez-torres/; accessed May 2020.

Freycinet, L. (1829). Voyage Autour Du Monde. Tome Deuxième. Imprimerie Royale, Paris.

García, F. (1683). Vida y Martirio del Venerable Padre Diego Luis de San Vitores. Imprenta de Juan García Infanzón, Madrid.

Giddens, A. (1991). Modernity and Self-Identity: Self and Society in Late Modern Age. Polity, Cambridge.

Giráldez, A. (2015). The Age of Trade: Manila Galleons and the Dawn of the Global Economy. Rowman and Littlefield, Lanham, MD.

González Marcén, P., Montón-Subías, S., and Picazo, M. (2008). Towards an Archaeology of Maintenance Activities. In Montón-Subías, S. and Sánchez Romero, M. (eds.), Engendering Social Dynamics: The Archaeology of Maintenance Activities. Archaeopress, Oxford, pp. 3-8.

González-Ruibal, A. (2014). An Archaeology of Resistance: Materiality and Time in an African Borderland. Rowman and Littlefield, Lanham, MD.

Graves, M. (1986). Organization and differentiation within late prehistoric ranked social units, Mariana Islands, Western Pacific. Journal of Field Archaeology 13: 139-154.

Graves, M., Hunt, T., and Moore, D. (1990). Ceramic production in the Mariana Islands: explaining change and diversity in prehistoric interaction and exchange. Asian Perspectives 29(2): 211-233.

Guha, R. and Spivak, G. (eds.) (1988). Selected Subaltern Studies. Oxford University Press, Oxford.

Hastrup, K. (ed.) (1992). Other Histories. Routledge, London.

Heathcote, G., Diego, V., Ishida, H., and Sava, V. (2012). An osteobiography of a remarkable protohistoric CHamoru man from Taga, Tinian. Micronesica 43(2): 131-213.

Hernando, A. (2002). Arqueología de la Identidad. Akal, Madrid.

Hernando, A. (2008). Why has history not appreciated maintenance activities? In Montón-Subías, S. and Sánchez Romero, M. (eds.), Engendering Social Dynamics: The Archaeology of Maintenance Activities. Archaeopress, Oxford, pp. 9-15.

Hernando, A. (2013). Change, individuality and reason: or how archaeology has legitimized a patriarchal modernity. In González-Ruibal, A. (ed.), Reclaiming Archaeology: Beyond the Tropes of Modernity. Routledge, London, pp. 155-67.

Hernando, A. (2018). The Fantasy of Individuality: On the Sociohistorical Construction of the Modern Subject. Springer, New York.

Hezel, F. (2015). When Cultures Clash: Revisiting the "Spanish-CHamoru Wars." Northern Marianas Humanities Council, Saipan. 
Hunter-Anderson, R.L. \& Butler, B. (1995). An Overview of Northern Marianas Prehistory. Saipan, MP: The Micronesian Archaeological Survey, Division of Historic Preservation, Dept. of Community Cultural Affairs.

Hunter-Anderson, R. L. (2011). The Latte Period in Marianas Prehistory. Who Is Interpreting It, Why and How Terra Australis 35: 17-28.

Ikehara-Quebral, R., and Douglas, M.T. (1997). Cultural alteration of human teeth in the Mariana Islands. American Journal of Physical Anthropology 104: 381-391.

Kant, E. (1991) [1784]. An Answer to the Question: What is Enlightment? Penguin Books, New York.

Kerr, A. (2013). Estevan Rodriguez's (1565 in Academia Real 1886): La Manera de Su Hablar, the First Lexicon of the CHamoru Language, Mariana Islands, Micronesia. University of Guam, Manguilao.

Laguana, A., Kurashina, H., Carson, M., Peterson, J., Bayman, J., Ames,T., Stephenson, R., Aguon, J., and Harya Putra, Ir. (2012). Estorian i Latte: a story of Latte. Micronesica 42(1/2): 80-120.

Ledesma, A. (1670). Noticias de los Progresos de Nuestra Santa Fe en las Islas Marianas. N. 31, Caja IMP-2-070 (31), Col. Montenegro, BHR, Granada, Spain.

Le Gobien, Ch. (1700). Histoire des Isles Marianes. Chez Nicolas Pepie, Paris.

Leon-Guerrero, J. (2019). Envisioning the past: near extinction. http://www.guampedia.com/envisioningthe-pastnear-extinction; accessed October 2020.

Lévesque, R. (1992a). History of Micronesia: A Collection of Source Documents. Vol. I. Lévesque Publications, Quebec.

Lévesque, R. (1992b). History of Micronesia: A Collection of Source Documents. Vol. II. Lévesque Publications, Quebec.

Lévesque, R. (1993). History of Micronesia: A Collection of Source Documents. Vol III. Lévesque Publications, Quebec.

Lévesque, R. (1995a). History of Micronesia: A Collection of Source Documents. Vol. IV. Lévesque Publications, Quebec.

Lévesque, R. (1995b). History of Micronesia: A Collection of Source Documents. Vol. V. Lévesque Publications, Quebec.

Lévesque, R. (1995c). History of Micronesia: A Collection of Source Documents. Vol VI. Lévesque Publications, Quebec.

Lévesque, R. (ed.) (2000). History of the Mission in the Mariana Islands:1667-1673, by Fr. Peter Coomans. CNMI Division of Historic Preservation, Saipan.

Lightfoot, K., Martinez, A., and Schiff, A. (2017). Daily practice and material culture in pluralistic social settings: an archaeological study of culture change and persistence from Fort Ross. American Antiquity 63(2): 199-222.

Lydon, J. (2009). Fantastic Dreaming: The Archaeology of an Aboriginal Mission. Altamira, Lanham, MD.

Lujan Bevacqua, M. \& Kelley Bowman, I. (2016). Histories of Wonder, Futures of Wonder: Chamorro Activist Identity, Community, y Leadership in "The Legend of Gadao" and "The Women Who Saved Guåhan from a Giant Fish". Marvels \& Tales 30(1): 70-89.

Lujan Bevacqua, M. (2020) Transmission of Christianity into CHamoru culture: an interpretive essay. http:// www.guampedia.com/transmission-of-christianity-into-CHamoru-culture/; accessed November 2020.

Manner, H. I. (2008). Directions for long term research in traditional agricultural systems of Micronesia and the Pacific Islands. Micronesica 40: 63-86.

Martínez, J. (ed.) (1997). Fray Juan Pobre de Zamora. Historia de la Pérdida y Descubrimiento del Galeón "San Felipe.” Institución "Gran Duque de Alba” de la Excma. Diputación Provincial de Ávila, Ávila.

McNeill, J. (2005). Putting the dead to work: an examination of the use of human bone in prehistoric Guam. In Rakita, G., Buikstra, J., and Beck. L. (eds.), Interacting with the Dead: Perspectives on Mortuary Archaeology for the New Millenium. University Press of Florida, Gainsville, pp. 305-315.

Merchant, C. (1980). The Death of Nature: Women, Ecology, and the Scientific Revolution. HarperCollins, New York.

Midgley, M. (2011). The Myths We Live By. Routledge, London.

Molina, M. (2013). To Overcome Oneself: The Jesuit Ethic and Spirit of Global Expansion, 1520-1767. University of California Press, Berkeley.

Montón-Subías, S. (2010). Maintenance activities and the ethics of care. In Dommesness, L. H., Hjørungdal, T., Montón-Subías, S., Sánchez-Romero, M., and Wicker, N. (eds.), Situating Gender in European Archaeologies. Archaeolingua, Budapest, pp. 23-33.

Montón-Subías, S. (2019). Gender, missions, and maintenance activities in the early modern globalization: Guam 1668-98. International Journal of Historical Archaeology 23: 404-429. 
Montón-Subías, S. and Hernando, A. (2018). Modern colonialism, eurocentrism and historical archaeology: some engendered thoughts. European Journal of Archaeology 21(3): 445-471.

Montón-Subías, S. and Moral de Eusebio, E. (2021). A body is worth a thousand words: early colonial dresscapes in Guam. Historical Archaeology 55(2): 269-289.

Montón-Subías, S., Moragas, N., and Bayman, J. (2020). The first missions in Oceania: excavations at the colonial church and cemetery of San Dionisio at Humåtak (Guam, Mariana Islands). Journal of Pacific Archaeology 11(2): 62-73.

Moore, D. (2005). Archaeological evidence of a prehistoric farming technique on Guam. Micronesica 38(1): 93-120.

Moore, D. (2012). What's new and what's cooking in the latte period pots. Micronesica 42(1): 121-147.

Moral de Eusebio, E. (2016). Heterotopías en conflicto: sexualidad, colonialismo y cultura material en las Islas Marianas durante el siglo XVII. In Coelho, I. P., Torres, J., Serrão, L., and Ramos, T. (eds.), Entre Ciência e Cultura: Da Interdisciplinaridade à Transversalidade da Arqueología (Actas das VIII Jornadas de Jovens em Investigação Arqueológica). CHAM, IEM, Lisbon, pp. 229-232.

Mumford, L. (1967). The Myth of the Machine. Vol. I: Technics and Human Development. Harcourt, Brace and World, San Diego.

Na'puti, T. R., and Lujan Bevacqua, M. (2015). Militarization and resistance from Guåhan: protecting and defending Pågat. American Quarterly 67(3): 837-858.

Ong, W. (1982). Orality and Literacy.The Technologizing of the Word. Routledge, London and New York.

Panich, L. (2013). Archaeologies of persistence: reconsidering the legacies of colonialism in Native North America. American Antiquity 78(1): 105-122.

Pauketat T. (ed.) (2001). The Archaeology of Traditions: Agency and History Before and After Columbus. University of Florida Press, Gainesville.

Peña, V. (2020). Alimentación y Colonialismo en las Islas Marianas (Pacífico Occidental): Introducciones, Adaptaciones y Transformaciones Alimentarias durante la Misión Jesuita (1668-1769). Doctoral dissertation, Universitat Pompeu Fabra, Barcelona.

Perez Hattori, A. (2007). Preservation for our souls: lessons from University of Guam students at historic Inalahan. In Stonework Heritage in Micronesia. Spanish Program for Cultural Cooperation, Guam Preservation Trust and Historic Resources Division, Guam Department of Parks and Recreation, Tumon, pp. 131-143.

Perez Hattori, A. (2018). Textbook tells: gender, race, and decolonizing Guam history textbooks in the 21st century. AlterNative 14(2): 173-184.

Perez Viernes, J. (2016). Hurao revisited: hypocrisy and double standards in contemporary histories and historiographies of Guam. Third Marianas History Conference, Guampedia, Manguilao, pp. 122-137.

Peterson, J. (2012). Latte villages in Guam and the Marianas: monumentality or monumenterity? Micronesica 42: 183-208.

Pezzarossi, H. (2014). Assembling indigeneity: rethinking innovation, tradition and indigenous materiality in a $19^{\text {th }}$ century native toolkit. Journal of Social Archaeology 14(3): 340-360.

Pietrusewsky, M., Douglas, M., Swift, M., Harper, R., and Fleming, M. (2014). Health in ancient Mariana islanders: a bioarchaeological perspective. Journal of Island and Coastal Archaeology 9(3): 319-340.

Pigafetta, A. (1525). Primo Viaggio in torno al Globo Terracqueo. Vol. 2: Reprod. facs. del ms. L 103 Sup. de la Biblioteca ambrosiana. Ediciones Grial, Valencia.

Quimby, F. (2011). The Hierro Commerce. Journal of Pacific History 46(1): 1-26.

Ribadeneira, M. (1601). Historia de las Islas del Archipiélago y Reinos de la Gran China: Tartaria, Cuchinchina, Malaca, Sian, Camboya y Japón, y de lo Sucedido en ellos a los Religiosos Descalzos de la Orden del Seráfico Padre San Francisco, de la Provincia de San Gregorio de las Filipinas. Imprenta de Gabriel Graells y Giraldo Dotil, Barcelona.

Russell, S. (1998). Tiempon I Manmofo'na: Ancient CHamoru Culture and History of the Northern Mariana Islands. División of Historic Preservation, Saipan.

Sahlins, M. (1985). Islands of History. University of Chicago Press, Chicago.

Sanvitores, D. L., Casanova, P., Morales, L., Cardeñoso, T., and Bustillo, L. (1671). Noticias de las Islas Marianas de los Años de 1670 y 1671. Philipp. 13, 56r-57v, ARSI, Rome, Italy.

Schreiber, L. L. and Mitchell, M. D. (eds.) (2010). Across a Great Divide: Continuity and Change in Native North American Societies, 1400-1900. University of Arizona Press, Tucson.

Silliman, S. (2009). Change and continuity, practice and memory: Native American persistence in colonial New England. American Antiquity 74(2): 211-230.

Souder, L. (1992). Daughters of the Island: Contemporary CHamoru Women Organizers on Guam. University Press of America, Lanham, MD. 
Stodder, A., Ryan, E., Hunter-Anderson, R., Douglas, M., and Ikehara-Quebral, R. (2015). Under the Latte: osteobiography and social context of a burial assemblage at Tumon Bay, Guam. In Oxenham, M. and Buckley, H. (eds.), The Routledge Handbook of Bioarchaeology in Southeast Asia and the Pacific Islands. Routledge, New York, pp. 527-568.

Swidler, N., Dongoske, K., Anyon, R., and Downer, A. (eds.) (1997). Native Americans and Archaeologists: Stepping Stones to Common Ground. Altamira, Walnut Creek, CA.

Taitano DeLeslie, C. (2015). A history of CHamoru nurse-midwives in Guam and a "Placental Politics" for Indigenous feminism. Intersections: Gender and Sexuality in Asia and the Pacific, 37. https://www. intersections.anu.edu.au/issue37/delisle.htm; accessed September 2020.

Taitano, G. (2019). Kumision I Fino' Chamorro/Chamorro Language Commision. https://www.guampedia. com/kumision-i-fino-chamorrochamorro-language-commission/; accesed June 2021.

Thompson, E. P. (1970). Time, work-discipline, and industrial capitalism. Past and Present 38: 55-97.

Thompson, L. (1945). The Native Cultures of the Mariana Islands. Bernice P. Bishop Museum, Honolulu. Thompson, L. (1947). Guam and Its People. Princeton University Press, Princeton, NJ.

Tolentino, D. (2019). Floren Paulino. https://www.guampedia.com/floren-paulino/; accessed May 2020.

Wagner, P. (2016). Progress: a Reconstruction. Polity Press, Cambridge.

Walth, Ch. (2016). Archaeological Investigations at the Naton Beach Site, Tumon, Guam. Vol. I. SWCA, Bridgeville, PA.

Wright, D. and Ricardi, P. (2015). Both sides of the frontier: the "contact" archaeology of villages on Mabuyaq, western Torres Strait. Quaternary International 385: 102-111.

Publisher's Note Springer Nature remains neutral with regard to jurisdictional claims in published maps and institutional affiliations. 